\title{
New estimates of early post-settlement mortality for intertidal mussels show no relationship with meso-scale coastline topographic features
}

\author{
Charles E. O. von der Meden ${ }^{1,2, *}$, Francesca Porrii ${ }^{1}$, Christopher D. McQuaid ${ }^{1}$ \\ ${ }^{1}$ Coastal Research Group, Department of Zoology and Entomology, Rhodes University, Grahamstown 6140, South Africa \\ ${ }^{2}$ Present address: South African Environmental Observation Network, Egagasini Node, 5th flr Foretrust Building, \\ Martin Hammerschlag Way, Cape Town, Private Bag X2, Roggebaai 8012, South Africa
}

\begin{abstract}
For organisms with planktonic larvae, the early post-settlement stage is a particularly vulnerable one, likely to influence distribution patterns in subsequent life stages. Although substantial post-settlement mortality is well known in several marine invertebrate taxa (e.g. barnacles), few estimates exist for benthic invertebrates, such as mussels, that have mobile settlers. Furthermore, estimates of early post-settlement mortality (within $2 \mathrm{~d}$ of settlement) are sparse for most groups. In addressing the difficulties involved with quantifying early mortality of mobile settlers, the present study builds on a sequential-deployment method to estimate the post-settlement mortality of the intertidal mussel Perna perna. Trials were run at 16 sites, split evenly between bay and open coast locations, and were repeated over 2 sampling cycles. By comparing post-settlement mortality estimates from bays and open coast sites, we investigated whether such topographic features produce differential mortality. Post-settlement mortality estimates showed substantial levels of mortality but did not differ significantly between bay and open coast sites. Early post-settlement mortality (i.e. mortality of primary settlers up to $2 \mathrm{~d}$ old) ranged from 31 to $94 \%$ but averaged 54 and $64 \%$ in the 2 sampling cycles. Estimates of total post-settlement mortality (i.e. inclusive of primary and secondary settlers) had a similar range and averaged $66 \%$ in Cycle 1 and $67 \%$ in Cycle 2. Apart from confirming significant mortality rates of early mussel settlers, these findings suggest that intertidal abundance patterns of recruits and adults, often associated with topographic features of coastlines, are more likely a result of initial settlement patterns than of differences in post-settlement mortality.
\end{abstract}

KEY WORDS: Post-settlement mortality $\cdot$ Coastline topography $\cdot$ Bays $\cdot$ Perna perna $\cdot$ Intertidal mussels $\cdot$ Pelagic-benthic coupling

\section{INTRODUCTION}

Substantial mortality during early post-settlement life has long been suggested and demonstrated across several marine taxa (Connell 1961, Thorson 1966, Gosselin \& Qian 1997, Hunt \& Scheibling 1997), including reef fish (Searcy \& Sponaugle 2001, Doherty et al. 2004), mobile invertebrates such as crabs, abalone and other gastropod species (Ray \& Stoner 1995, Moksnes et al. 1998, Naylor \& McShane
2001) and a variety of sessile invertebrates (Hurlbut 1991, Gosselin \& Qian 1996, Marshall \& Keough 2003). Certainly, juvenile mortality in benthic marine invertebrates is greater than $90 \%$ in the majority of studies (Gosselin \& Qian 1997), identifying this period as especially important in the life history progression of benthic organisms.

While the relevance and severity of post-settlement mortality is recognized (see Gosselin \& Qian 1997, Hunt \& Scheibling 1997, Shanks 2009), it is a difficult 
parameter to quantify, particularly for invertebrate organisms with mobile settlers. In general, monitoring of early settlers must be frequent enough to allow separation of the initial settlement pattern from the mortality-altered post-settlement pattern (Hunt \& Scheibling 1997). This requirement of high frequency sampling (Minchinton \& Scheibling 1993), together with the small size of early settlers makes studies of mortality within the first 24 to 48 h exceedingly difficult (Hunt \& Scheibling 1997). Much of our knowledge of post-settlement processes and their importance to benthic invertebrate populations comes from the study of barnacles (Foster 1971, Connell 1985, Wethey 1985, Jarrett 2000, Chan \& Williams 2003). Some direct estimates of mortality within 2 to $4 \mathrm{~d}$ of settlement are available for several other taxa, including ascidians, bryozoans, oysters and gastropods (Davis 1987, Stoner 1990, Ray \& Stoner 1995, Gosselin \& Qian 1996, Walters \& Wethey 1996, Naylor \& McShane 2001). For many groups, including bivalves, post-settlement mortality estimates pertain largely to older settlers and recruits (e.g. Luckenbach 1984, Bartol et al. 1999, Bishop et al. 2005). As a result, little is known about typical levels of early (ca. 2 d) post-settlement mortality, particularly for mussels (but see Bownes \& McQuaid 2009).

In this regard, the lack of studies on bivalves (and mussels in particular) suggests that establishing early mortality of mussels is especially difficult. Relative to barnacles, the mobility of mussel settlers makes distinguishing between real mortality and emigration (post-settlement movement, sensu Bayne 1964) virtually impossible. Consequently, standard techniques of mapping or photographing experimental plates, such as are used for barnacles (Gosselin \& Qian 1997), cannot be employed. Traditional cohort monitoring, or variants of this technique, have been used with some success, finding high rates of mussel mortality within various sampling intervals (Moreno 1995, Cole et al. 2000, McQuaid \& Phillips 2007, Peteiro et al. 2007).

Although previous methods of marking or tagging mussel settlers in the numbers necessary for meaningful experimentation have proved unsuccessful (Seed 1969), recent advances, such as the use of calcein staining, have made this method one of the most reliable (Phillips 2002, 2004). Staining methods, however, retain the problem of separating emigration derived losses from actual mortality. Other methods such as the use of caged plots have successfully obtained estimates of monthly juvenile mussel mortality (75-100\%) but are only able to explore certain sources of mortality (e.g. Shields et al. 2008).
Most notably, Bownes \& McQuaid (2009) used a novel method of sequential deployment of paired settler collectors to estimate juvenile mussel mortality over $6 \mathrm{~d}$. Mortality was calculated by subtracting the total settlement on the settlement pads left in place for the duration of the experiment (' $6-d$ pads') from the cumulative settlement on successive daily pads and expressing this as a percentage of the cumulative daily settlement. As in other studies such as Shanks (2009), discrete daily settlement was essentially considered mortality free. In Bownes \& McQuaid's (2009) calculations, 'settlement' included all sizes of settlers, and it was assumed that there were no differences in attraction of settlers to the 'clean' daily collectors and the established weekly collectors. In reality, weekly collectors would have rapidly developed bacterial communities and biofilms, probably within the first $24 \mathrm{~h}$ of being deployed (Zobell \& Allen 1935), and would have carried increasing numbers of conspecific settlers. These factors have been found to increase primary and secondary mussel settlement, respectively (von der Meden et al. 2010).

Primarily, the present study further develops the sequential-deployment method of Bownes \& McQuaid (2009), taking into account differences in settler attraction to biofilms and conspecifics, to estimate early post-settlement mortality of the intertidal mussel Perna perna on the south coast of South Africa (Fig. 1). Using these estimates, this study examines the influence of coastal topographic features (bays/headlands) on post-settlement mortality. In the study area, settlement and the abundance of adult intertidal mussels are greater in bays than on the open coast (C.E.O. von der Meden unpubl., von der Meden et al. 2008). How this pattern comes about is not known, although a supply-side influence has been suggested here and in several other regions (e.g. Helson \& Gardner 2004, Lagos et al. 2005, Pfaff et al. 2011). An additional explanation, however, may lie in patterns of post-settlement mortality. Since juvenile survival can be affected by physiological stresses related to desiccation or emersion (Tan 1975, Iwasaki 1995) and latent effects of larval food availability (Phillips 2002, 2004), differences in exogenous 'causal' factors between bay and open coast habitats (such as wave exposure) may well drive patterns of post-settlement mortality (e.g Gosselin \& Chia 1995, Naylor \& McShane 2001). By investigating postsettlement mortality across multiple bays and open coast sites, we test the hypothesis that postsettlement mortality is lower in bays than on the open coast. 


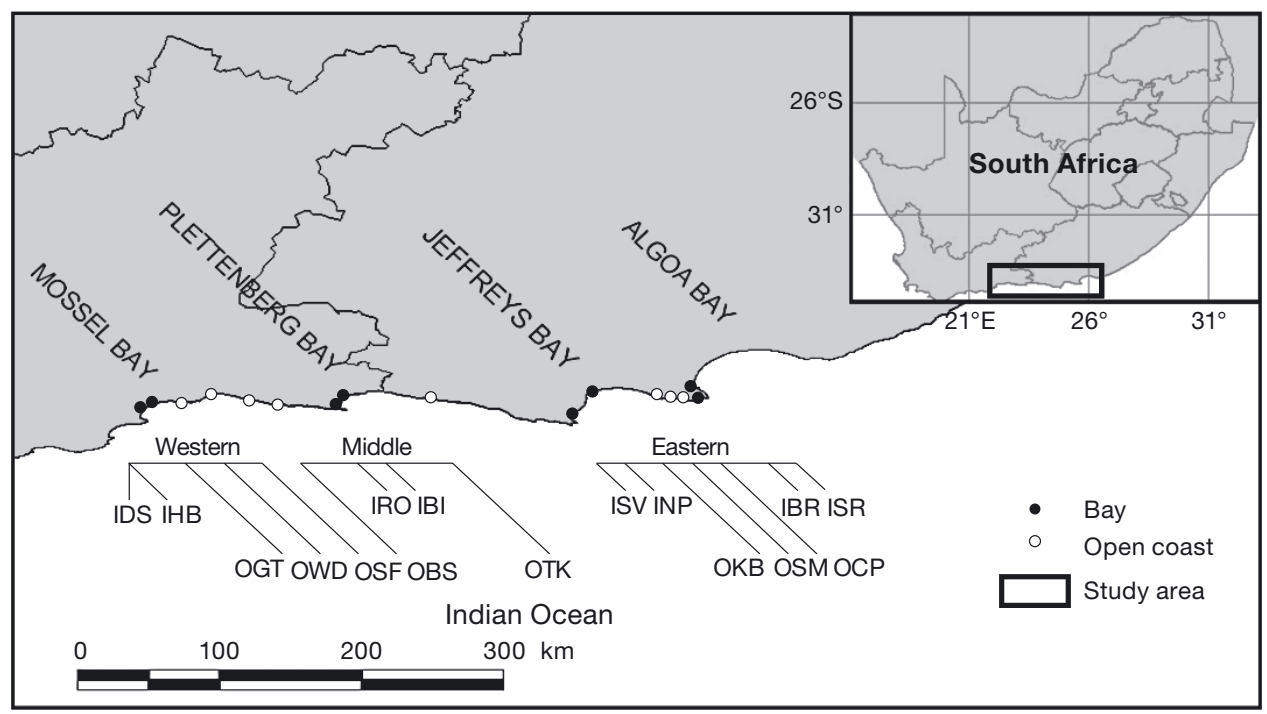

Fig. 1. Study sites along the south coast of South Africa. Bay sites have the prefix 'I'; open coast sites have the prefix 'O'

\section{MATERIALS AND METHODS}

\section{Experimental setup}

Following Bownes \& McQuaid (2009), paired larval collectors (plastic mesh pot-scourers) were deployed on low-shore rocks (within the lower balanoid zone) in 3 replicate pairs at each of 16 sites. Collectors were attached in pairs to individual eye bolts, which were separated by $>50 \mathrm{~cm}$. Sites were split evenly between bay and open coast habitats (Fig. 1). One collector from each pair was replaced daily while the other remained in place for the $7 \mathrm{~d}$ duration of the experiment.

Because sites were spread out over a considerable distance (ca. 500 km, Fig. 1), the study area was subdivided into 3 sections. The most easterly of these sections included 7 sites (ISV, INP, OKB, OSM, OCP, IBR, ISR) the middle section 4 (OBS, IRO, IBI, OTK) and the westerly section 5 (IDS, IHB, OGT, OWD, OSF) (Fig. 1). Each section was sampled over a week, collecting and replacing the daily collectors every morning during low spring tides. Sampling of the first section began on 18 January 2007, with the middle and western sections being sampled on the 2 subsequent spring tides (starting 31 January and 15 February, respectively). This procedure was repeated directly after the completion of this first 3-section 'cycle', starting with the eastern section on 1 March, and sampling the middle and western sections starting on 15 March and 1 April, respectively. This produced 2 sampling cycles of 3 sections each: Cycle 1 and 2. Collectors were stored in jars of $70 \%$ ethanol immediately after collection.

\section{Laboratory procedures}

Collectors were soaked for 3 min in a weak (20\%) sodium hypochlorite solution to dissolve byssal threads, allowing easy removal of settlers (Davies 1974). The collectors were then vigorously washed and all material collected in a $75 \mu \mathrm{m}$ sieve. All Perna perna settlers were identified following Bownes et al. (2008) and enumerated. Larval collectors often contain a range of sizes of post-larval mussels, even if recovered from the shore after only $24 \mathrm{~h}$. These include primary settlers and those that have immigrated as secondary settlers. We separated mussels into 3 size classes: primary settlers $(<360 \mu \mathrm{m})$; primary settlers plus $1 \mathrm{wk}$ of growth (360-660 $\mu \mathrm{m}$, referred to as size class B); and secondary settlers/ recruits (>660 $\mu \mathrm{m}$, referred to as size class $\mathrm{C}$ ). The range for the middle size class (B) was based on potential weekly growth from a minimum initial settlement size of $260 \mu \mathrm{m}$ or a maximum initial settlement size of $360 \mu \mathrm{m}$, calculated using growth rates estimated by Bownes (2005) for the study species $\left(12 \pm 8.4\right.$ to $32.5 \pm 5.0 \mu \mathrm{m} \mathrm{d}^{-1}$, mean $\left.\pm \mathrm{SD}\right)$.

\section{Calculation of post-settlement mortality}

In refining the methods of Bownes \& McQuaid (2009), the present study separated primary postsettlement mortality (i.e. mortality of primary settlers) and total post-settlement mortality (i.e. mortality of all individuals arriving on collectors). Both biofilm and the presence of conspecifics have been shown to 
affect settlement rates (von der Meden et al. 2010), so we incorporated field-derived correction factors to compensate for these effects on weekly collectors. Correction factors were determined for the study species by analogous week-long manipulative experiments at 2 sites, which estimated the effects of both biofilm and the presence of conspecifics on settlement rates (see von der Meden et al. 2010 for detailed methods). In the present study, correction factors were applied to daily settlement rates from Day 2 onwards, allowing $24 \mathrm{~h}$ for the establishment of biofilms and arrival of conspecifics on the weekly collectors. The equations were developed as follows:

\section{Primary post-settlement mortality}

The corrected cumulative (total) primary settlement $\left(D_{\mathrm{ps}}\right)$ on daily collectors was calculated using Eq. (1.1), where $D_{1 \mathrm{ps}}$ is the primary settlement (ps) on the Day 1 daily collector (uncorrected for biofilm and conspecifics), and $\sum D_{2-7 \mathrm{ps}}$ is the sum of primary settlers from Days 2-7, which was multiplied by the primary settler correction factor $C_{1}=3.8$, derived from von der Meden et al. (2010).

$$
D_{\mathrm{psT}}=D_{1 \mathrm{ps}}+D_{2-7 \mathrm{ps}} C_{1}
$$

The total number of primary settlers on each weekly collector $\left(W_{\mathrm{psT}}\right)$ was calculated according to Eq. (1.2), where $W_{\mathrm{ps}}$ is the number of primary settlers on the weekly collector; $W_{\mathrm{B}}$ is the number of settlers of size class B (360-660 $\mu \mathrm{m})$ on the weekly collector (indicating the number of settlers that either grew out of the primary settler size class during the week or immigrated to the weekly collector at a size larger than $360 \mu \mathrm{m})$; and $\Sigma D_{1-7 \mathrm{~B}}$ is the sum of settlers on the daily collectors that were of size class B. Since settlers of size class B on daily collectors must have immigrated rather than settled and grown, this sum $\left(\Sigma D_{1-7 \mathrm{~B}}\right)$ provides an estimate of immigration at a given site. Subtracting this estimate of immigration from $W_{\mathrm{B}}$ leaves the number of primary settlers that had arrived on a weekly collector but grew out of the primary size class into class B during the sampling week. $W_{\text {psT }}$ is therefore simply the total number of primary settlers on the weekly collector, including those that were no longer in the primary settler class at the end of the experiment.

$$
W_{\mathrm{psT}}=W_{\mathrm{ps}}+\left(W_{\mathrm{B}}-\sum D_{1-7 \mathrm{~B}}\right)
$$

Note that no correction factor was applied to the daily immigrants $\left(\sum D_{1-7 \mathrm{~B}}\right)$ in Eq. (1.2) since no effect of biofilm or conspecific presence was found for this size class (von der Meden et al. 2010). Putting Eqs. (1.1) \& (1.2) together, mortality of primary settlers, or primary post-settlement mortality ( $M_{\text {primary }}$ ) over the $7 \mathrm{~d}$ duration of the experiment, was calculated as follows:

$$
M_{\text {primary }}=\frac{D_{\mathrm{psT}}-W_{\mathrm{psT}}}{D_{\mathrm{psT}}} \times 100 \quad \text { Eq. (1.3) }
$$

The calculation of $M_{\text {primary }}$ as described by Eqs. (1.1) to (1.3) has several difficulties and comes with 5 assumptions:

(1) There is negligible mortality on daily collectors, within each $24 \mathrm{~h}$ deployment time, relative to the corresponding weekly collectors.

(2) We are forced to assume that mortality of $W_{\mathrm{B}}$ settlers (Eq. 1.2) is negligible.

(3) Rates of immigration and emigration of settlers to and from collectors are assumed to be similar if not equal and therefore balance each other. Based on this assumption, calculated mortality rates describe only those settlers that die.

(4) Differential settler attraction to weekly collectors remains relatively consistent across sites and in time, meaning the calculated correction factor adequately accounts for these differences at all sites.

(5) Given no increased attraction of size class B to biofilm (sensu von der Meden et al. 2010), it is assumed that the $\sum D_{1-7 \mathrm{~B}}$ (Eq. 1.2) approximates immigration onto weekly collectors.

\section{Total post-settlement mortality}

Total post-settlement mortality $\left(M_{\text {total }}\right)$ was calculated by subtracting the total number of settlers of all 3 size classes on the weekly collector ( $\left.W_{\mathrm{TS}}\right)$ from the cumulative settlement of all 3 size classes on the 7 daily collectors (total daily settlement, $D_{\mathrm{TS}}$ ). $C_{1}$ was applied to the daily primary settlers as in Eq. (1.1). A second correction factor $\left(C_{2}=6.6\right)$ was applied to size class $\mathrm{C}$. This corrected for the combined effect of biofilm and conspecifics on these larger recruits, as calculated by von der Meden et al. (2010). $D_{\text {TS }}$ was calculated as:

$D_{\mathrm{TS}}=\left(D_{1 \mathrm{ps}}+\sum D_{2-7 \mathrm{ps}} C_{1}\right)+\sum D_{1-7 \mathrm{~B}}+\left(D_{1 \mathrm{C}}+\sum D_{2-7 \mathrm{C}} C_{2}\right)$ Eq. (2.1)

and $W_{\text {TS }}$ as:

$$
W_{\mathrm{TS}}=W_{\mathrm{ps}}+W_{\mathrm{B}}+W_{\mathrm{C}} \quad \text { Eq. (2.2) }
$$

$M_{\text {total }}$ for the 1 wk period was therefore calculated from $D_{\mathrm{TS}}$ and $W_{\mathrm{TS}}$ as follows: 


$$
M_{\text {Total }}=\frac{D_{\mathrm{Ts}}-W_{\mathrm{TS}}}{D_{\mathrm{Ts}}} \times 100 \quad \text { Eq. }(2.3)
$$

The terms for Eqs. (2.1) to (2.3) are the same as in Eqs. (1.1) to (1.3), with the addition of $D_{1 \mathrm{C}}$, the number of settlers of size class $C$ on the Day 1 daily collector; $\sum D_{2-7 \mathrm{C}} C_{2}$, the corrected sum of settlers of size class $C$ on daily collectors from Day $2-7$, and finally $W_{\mathrm{C}}$, the number of weekly settlers in size class C. Assumptions (1) and (3) above also apply to the calculation of total post-settlement mortality.

\section{Data handling and statistical analyses}

Mortality was calculated for all sites; however, the stochastic nature of settlement means that weekly and daily collectors on the same eye bolt inevitably differ in the number of settlers arriving on them, with the difference ranging between positive and negative so that subtracting weekly settlement from cumulative daily settlement should result in a normally distributed spread of values. Because of this and the possibility of non-conformance to the assumptions of the equations (above), some post-settlement mortality percentages were biologically unrealistic (i.e. outside the $0-100 \%$ range). These were therefore not included in statistical analyses.

Two-way ANOVAs were used to examine primary and total post-settlement mortality in each of the 2 sampling cycles. These analyses tested for effects of topography (fixed, 2 levels: bay and open coast) and site (random, nested in topography) using all data within the $0-100 \%$ range in each case.

\section{Settlement rates and assumptions}

To try to understand why so many mortality percentages were not realistic, we examined the potential influence of our assumptions on primary post-settlement mortality estimates. This was done using hypothetical cases, each correcting for the situation arising from non-conformance to a particular assumption. For example, increasing the number of primary settlers on daily collectors $\left(D_{1 \mathrm{ps}}\right.$ and $D_{2-7 p s}$ Eq. 1.1) corrects for the possibility of nonconformance with Assumption 1 (negligible mortality of daily settlers). This provided a way of modelling the influence of different terms in the post-settlement mortality equation on our mortality estimates, as each term or group of terms can be related to a specific assumption. Increases or decreases in equation terms were arbitrarily chosen, and involved doubling, tripling and quadrupling or reducing by half, a third and a quarter (see Table 1). In the case of changes to $C_{1}$ (3.8) a lower value of 1.5 and 2 higher values 5 and 8 were selected for modelling.

\section{RESULTS}

\section{Settlement patterns}

Cumulative daily settlement of all 3 size classes displayed order-of-magnitude differences among several of the 15 study sites (reduced from 16 sites due to loss of Site OCP in this cycle) as seen in Cycle 1 (Fig. 2). Of the 3 size classes, primary settle-

Table 1. Summary results from modelling of the primary post-settlement mortality equation. Equation terms were altered to simulate non-conformance of a particular assumption. The range of alterations is shown as the factor by which a given term was multiplied. The direction of change produced in the mortality estimates is described and the number of additional realistic estimates rendered is listed in the final column. $D_{\mathrm{ps}}$ : cumulative primary settlement on daily collectors; $D_{\mathrm{ps}}$ : primary settlers on Day 1 daily collector; $D_{2-7 p s}$ : primary settlers from daily collectors over Days $2-7 ; W_{\mathrm{B}}$ : number of settlers of size class B on weekly collectors; $C_{1}$ : primary settler correction factor; $\sum D_{1-7 \mathrm{~B}}$ : sum of settlers on daily collectors that were size class $\mathrm{B}_{i}$ +ve: positive; -ve: negative

\begin{tabular}{|c|c|c|c|c|}
\hline Relevant assumption & $\begin{array}{l}\text { Terms } \\
\text { altered }\end{array}$ & $\begin{array}{l}\text { Range of } \\
\text { alterations }\end{array}$ & $\begin{array}{l}\text { Direction } \\
\text { of result }\end{array}$ & $\begin{array}{l}\text { No. additional } \\
\text { realistic percentages }\end{array}$ \\
\hline $\begin{array}{l}\text { (1) Negligible daily mortality } \\
\text { (higher } D_{\mathrm{psT}} \text { to compensate for mortality) }\end{array}$ & $\begin{array}{l}D_{1 \mathrm{ps}} \& D_{2-7 \mathrm{ps}} \\
\text { Eq. (1.1) }\end{array}$ & $\times 2,3,4$ & $\begin{array}{l}\text { Lowers +ve but } \\
\text { increases -ve percentages }\end{array}$ & $2-7$ \\
\hline $\begin{array}{l}\text { (2) Negligible mortality } W_{\mathrm{B}} \\
\text { (higher } W_{\mathrm{B}} \text { to compensate for mortality) }\end{array}$ & $W_{\mathrm{B}}, \mathrm{Eq} \cdot(1.2)$ & $\times 2,3,4$ & $\begin{array}{l}\text { All percentages get } \\
\text { smaller as } W_{\mathrm{B}} \text { increases }\end{array}$ & $4-5$ \\
\hline $\begin{array}{l}\text { (4) Consistent correction factor } \\
\text { (higher or lower correction factor) }\end{array}$ & $C_{1}$, Eq. (1.1) & $C_{1}=1.5,5,8$ & $\begin{array}{l}\text { Higher } C_{1}=\text { lowers +ve but } \\
\text { increases -ve percentages }\end{array}$ & $2-6$ \\
\hline $\begin{array}{l}\text { (5) \& (3) Weekly immigration = cumu- } \\
\text { lative daily (higher or lower immigration) }\end{array}$ & $\sum D_{1-7 \mathrm{~B}}$, Eq. (1.2) & $\begin{array}{c}\times 2,3,4 \\
\times 0.5,0.33,0.25\end{array}$ & $\begin{array}{l}\text { Percent changes in } \\
\text { direction of alteration }\end{array}$ & $2-6$ \\
\hline
\end{tabular}




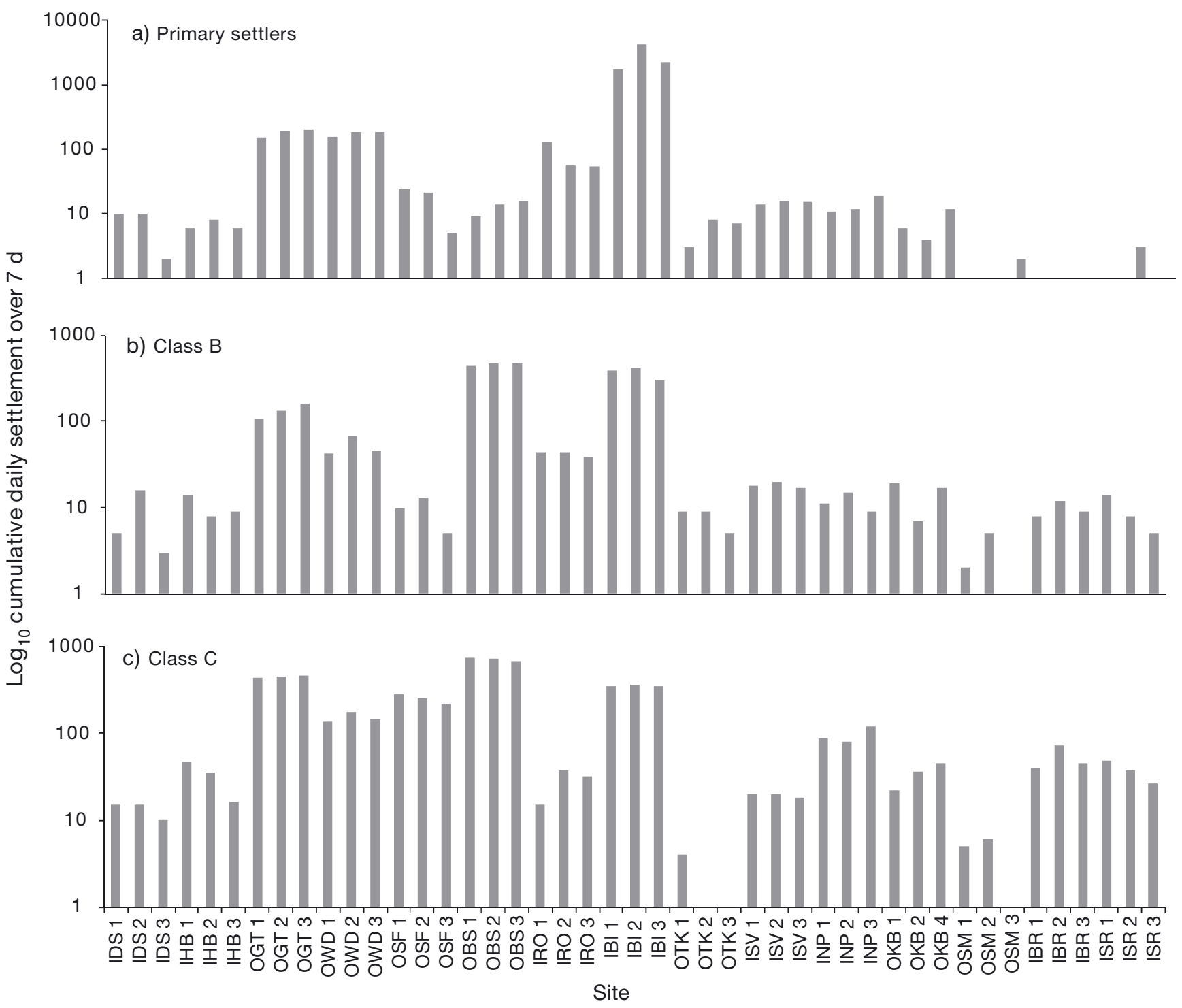

Fig. 2. Log-scaled cumulative daily settlement in each size class (a) primary settlers $(<360 \mu \mathrm{m})$, (b) size class B (360-660 $\mu \mathrm{m})$ and (c) size class C (>660 $\mu \mathrm{m})$. Cumulative settlement values are summed over 7 daily collections. Sites are in geographical order from west to east. As in Fig. 1, site codes for bays have the prefix 'I'; open coast sites have the prefix 'O', with numbers 1 to 3 indicating replicates

ment was particularly variable, having the greatest number of replicates with zero settlement as well as the maximum cumulative settlement rate of 4216 settlers (over 7 d). For settlers between 360 and $660 \mu \mathrm{m}$ (size class B) a maximum cumulative settlement rate of 471 settlers was recorded, while for those larger than $660 \mu \mathrm{m}$ (size class C) the maximum cumulative rate was 756 settlers. Spatially, settlement patterns were similar across all 3 size classes. The general pattern was an increase in settlement from the westerly sites in Mossel Bay (IHB, IDS) to peak values in Brenton-on-Sea (OBS) and Plettenberg Bay (IBI), followed by decreasing rates across the easterly sites of the Algoa Bay area (ISR, IBR, OSM, OKB, see Fig. 2). The same pattern was evident in Cycle 2.

\section{Post-settlement mortality}

Estimates of primary post-settlement mortality varied greatly in both sampling cycles; an example of this can be seen in Cycle 1, for which 17 of the 45 replicate collector pairs produced biologically realistic primary mortality percentages within the range of 0 to $100 \%$ (Fig. 3a). A similarly wide range of estimates resulted from calculations of total post-settle- 

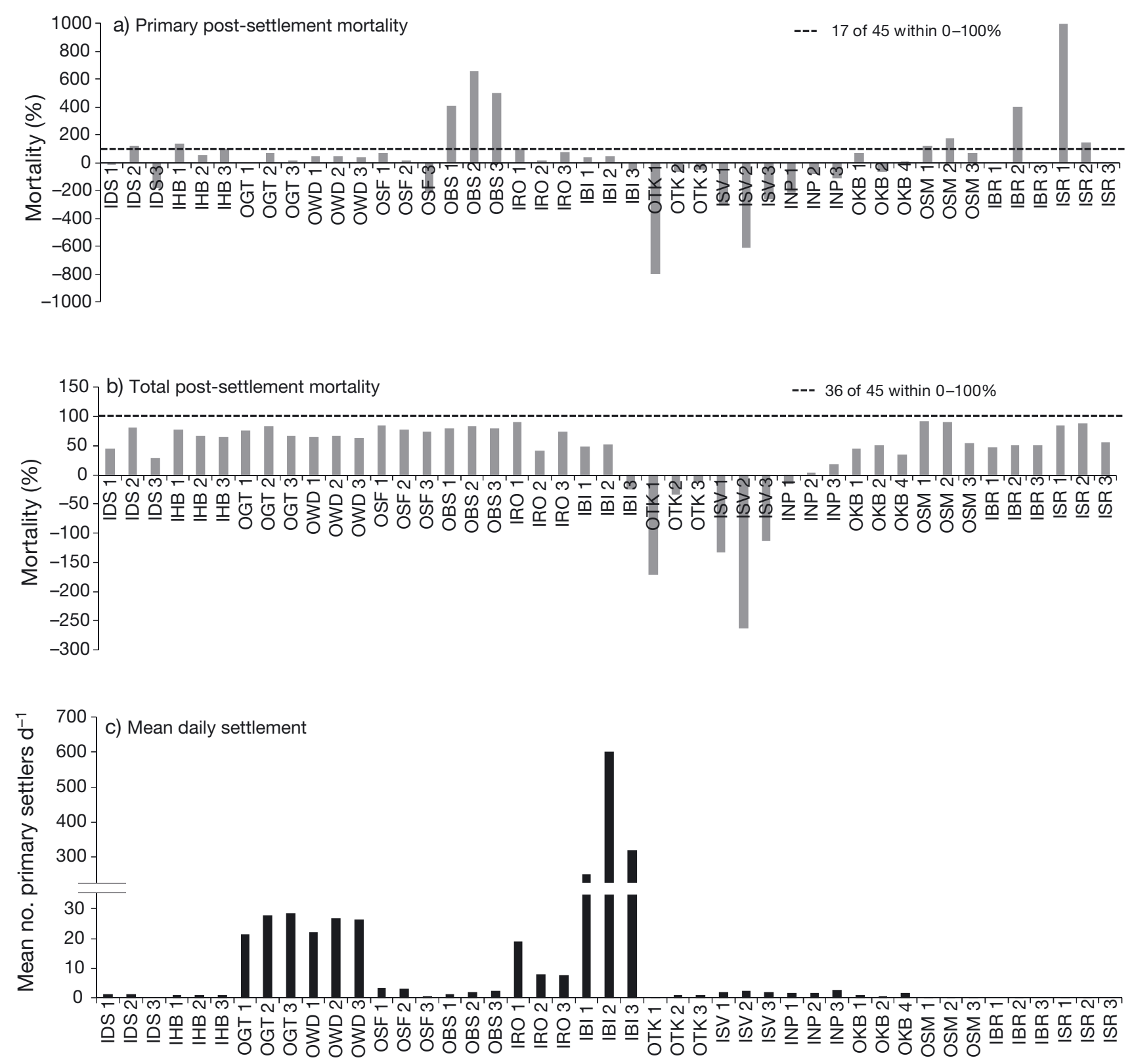

Site

Fig. 3. Calculated (a) primary and (b) total post-settlement mortality percentages for all 3 replicates at each of the 15 study sites from the first sampling cycle, Cycle 1. Bars with values between 0 and the dashed line (100\%) are the biologically realistic values calculated. (c) Mean daily primary settlement rate for corresponding replicates during Cycle 1. Sites are in geographical order from west to east. As in Fig. 1, site codes for bays have the prefix 'I'; open coast sites have the prefix ' $\mathrm{O}$ ', with numbers 1 to 3 indicating replicates

ment mortality, although many more fell within the biologically realistic range (36 of 45 collector pairs, Fig. 3b). Although not presented, numbers of biologically realistic percentages were very similar in Cycle 2 (19/48 for primary mortality; 38/48 for total mortality). No obvious pattern or relationship was noticed between mean daily settlement rates and the calculated mortality percentages (e.g. Fig. 3c).

\section{Modelling of assumptions}

Increasing $D_{\mathrm{psT}}$ (see Assumption 1) either directly through settler numbers or indirectly by changing $C_{1}$ (see Assumption 4) resulted in lower positive mortality percentages and smaller negative percentages, and improved the number of replicates with realistic mortality percentages by between 2 and 7 , depend- 
a) Cycle 1

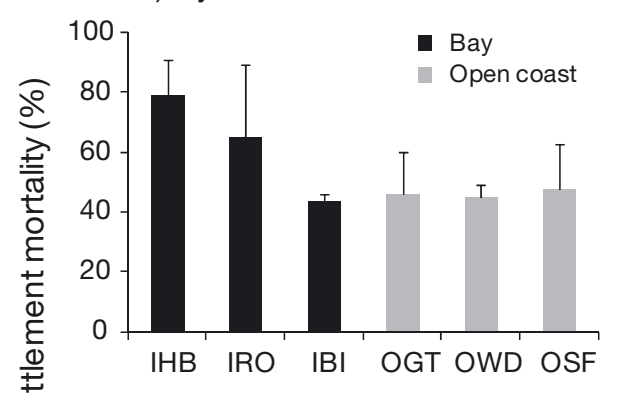

b) Cycle 2

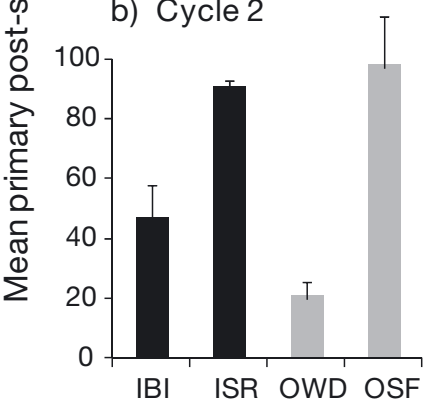

Fig. 4. Mean primary post-settlement mortality percentages $(+\mathrm{SE})$ calculated for sites in (a) Cycle $1(\mathrm{n}=6)$ and $(\mathrm{b})$ Cycle 2 $(\mathrm{n}=4)$. Within each topographic class, sites are arranged in geographic order from west to east (see Fig. 1)

ing on the amount increased (Table 1). By increasing the number of $W_{B}$ (Assumption 2), mortality percentages were lowered and the number of biologically realistic percentages was increased by 4 and 5 replicates (Table 1). Similarly, altering $\sum D_{1-7 \mathrm{~B}}$ (Assumption 5) caused the mortality percentages to shift in the direction of the alteration. Both increases and decreases in immigrating settlers produced between 2 and 6 additional realistic mortality percentages (Table 1).

\section{Topography-related patterns}

Using only biologically realistic sites in each case, the mean percent primary postsettlement mortality was $54.3 \%$ in Cycle 1 and $64.3 \%$ in Cycle 2 . On a by-site basis, mean primary post-settlement mortality ranged across sites from 43.2 to $78.7 \%$ in Cycle 1 and from 31.1 to $94.7 \%$ in Cycle 2 (Fig. 4). While the average mortality for bay sites was greater than that for open coast sites in both cycles, these differences between bay and open coast sites were not statistically significant (Table 2, Fig. 4).

The biologically realistic total post-settlement mortality percentages were similar to those of primary post-settlement mortality, with an overall mean of $65.9 \%$ in Cycle 1 and $67.2 \%$ in Cycle 2 . By site, total post-settlement mortality percentages ranged from 43.9 to $81.3 \%$ in Cycle 1 and from 49.2 to $81 \%$ in Cycle 2 (Fig. 5). As with primary postsettlement mortality, no effect of topography was found (Table 3, Fig. 5). Significant site-level differences were found in both cycles, but in each case, differences were among sites of one or the other topographic group. Student-Newman-Keuls post-hoc tests could not fully resolve these differences (Table 3).

\section{DISCUSSION}

Principally, our work adds methodologically and quantitatively to the small number of studies providing estimates of early post-settlement mortality (within the first $2 \mathrm{~d}$ of settlement) in benthic marine invertebrates, and to the even smaller number of works on bivalves (e.g. Roegner \& Mann 1995, Bownes \& McQuaid 2009). Clearly, in raw form our mortality equations and related assumptions did not give realistic estimates of mortality for all sites and replicates. However, modelling changes to the primary post-settlement mortality estimates showed that by altering daily settlement, immigration rates and the correction factor to simulate non-conformance with our original assumptions, the output of the primary post-settlement mortality equation could be improved in many instances (see Table 1). These improvements demonstrate that the poor performance of the equation was probably due to one or more of the assumptions not being met. Using the equation under our original assumptions, we obtained 17 of 45 realistic values. As our modelling

Table 2. ANOVA results for primary post-settlement mortality among sites in (a) Cycle $1(\mathrm{n}=6)$ and $(\mathrm{b})$ Cycle $2(\mathrm{n}=4)$. Italics denote significant $p$-values $(\alpha<0.05)$. SNK: Student-Newman Keuls test

\begin{tabular}{|lccccc|}
\hline Source & df & MS & $F$ & p & $F$ versus \\
\hline (a) Cycle 1 (n= 6) & & & & & \\
Topography & 1 & 1144.76 & 2.37 & 0.1986 & Site (Topography) \\
Site (Topography) & 4 & 483.256 & 0.81 & 0.5434 & Residual \\
Residual & 12 & 598.015 & & & \\
Total & 17 & & & & \\
(b) Cycle 2 (n= 4) & & & & & \\
Topography & 1 & 2657.52 & 1.53 & 0.3411 & Site (Topography) \\
Site (Topography) & 2 & 1731.45 & 4.81 & 0.0426 & RES \\
Residual & 8 & 360.311 & & & \\
Total & 11 & & & & \\
SNK could not resolve among-site differences & \\
\hline
\end{tabular}




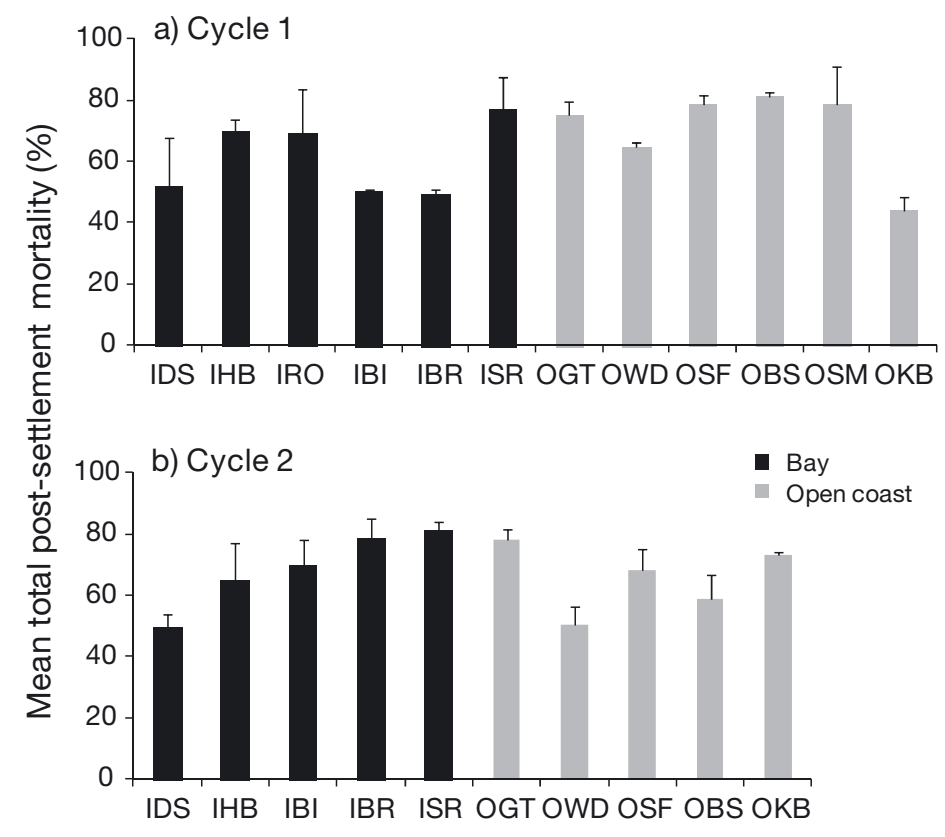

Fig. 5. Mean total post-settlement mortality percentages (+SE) calculated for sites in (a) Cycle $1(\mathrm{n}=12)$ and (b) Cycle $2(\mathrm{n}=10)$. Within each topographic class, sites are arranged in geographic order from west to east (see Fig. 1)

showed, however, this number can be increased (e.g. to 24 of 45 , Table 1). With more accurate estimation of daily mortality parameters and immigration rates it will be possible to get many more realistic estimates from our equations.

The set of biologically realistic mortality estimates put forward in the present study are in agreement with several previous findings, including estimates for the study species (e.g. Gosselin \& Qian 1997, Bownes 2005), and put post-settlement mortality within the first $24 \mathrm{~h}$ of settlement at between ca. 54 and $64 \%$. These rates are, however, higher than findings for conch (20-40\% within ca. 2 d, Ray \& Stoner 1995) and abalone species (ca. 25-36\% within 3 d, Naylor \& McShane 2001). Estimates of total post-settlement mortality in the present study were also substantial (ca. $65-67 \%$ ) but these agree less consistently with results from other studies. For example, while Phillips $(2002,2004)$ found mortality over 2 wk to be between ca. 70 and $97 \%$ for Mytilus galloprovincialis, Bownes \& McQuaid (2009) showed a far lower range of between 0 and $30 \%$ mortality on the low shore over a $6 \mathrm{~d}$ period. The latter result is especially relevant to the present study as it describes mortality on the low shore, for the same species and from the same coast examined here. It could be that these low percentages were a result of increased attraction to established weekly collectors, which was unaccounted for in their study.

While post-settlement mortality varied among sites, there was no significant effect of topography on either primary or total postsettlement mortality; meaning that postsettlement mortality was similarly substantial across bay and open coast sites. This result suggests that wave exposure and other physical factors that differ between these habitats did not have a strong effect on early mussel mortality. Nicastro et al. (2008), however, showed a topographic (bay/open coast) effect on adult mussel mortality, with greater mortality on the open coast, suggesting that differences in wave exposure and other factors can act directly on adult mortality. A possible explanation for the lack of a topographic effect on post-settlement mortality could be that the minimum 'fatal' level of wave exposure for settlers lies below the level of wave action commonly occurring in bays on the study coast. In other words, mussel settlers may have been equally disturbed by wave action in both habitats. Nonetheless, the lack of differences in post-settlement mortality between bay and open coast shores suggests that patterns of greater recruitment and adult abundance in bays as seen in the study area and in several other regions (Gaines \& Bertness 1992, Helson \& Gardner 2004, McQuaid \& Phillips 2007,

Table 3. ANOVA results for total post-settlement mortality among sites in (a) Cycle 1 ( $\mathrm{n}=12)$ and (b) Cycle $2(\mathrm{n}=10)$. SNK: Student-NewmanKeuls test. As in Fig. 1, site codes for bays have the prefix 'I'; open coast sites have the prefix 'O'. Italics denote significant $\mathrm{p}$-values $(\alpha<0.05)$

\begin{tabular}{|c|c|c|c|c|c|}
\hline Source & df & MS & $F$ & $\mathrm{p}$ & $F$ versus \\
\hline \multicolumn{6}{|l|}{ (a) Cycle 1} \\
\hline Topography & 1 & 755.186 & 1.44 & 0.2577 & Site (Topography) \\
\hline Site (Topography) & 10 & 524.3 & 2.66 & 0.0243 & Residual \\
\hline Residual & 24 & 197.445 & & & \\
\hline Total & 35 & & & & \\
\hline \multicolumn{6}{|c|}{$\begin{array}{l}\text { SNK: OBS, OSM, OSF, OGT }=\text { OWD }>\text { OKB }=\text { OWD, remainder not } \\
\text { resolved }\end{array}$} \\
\hline \multicolumn{6}{|l|}{ (b) Cycle 2} \\
\hline Topography & 1 & 57.9118 & 0.14 & 0.7228 & Site (Topography) \\
\hline Site (Topography) & 8 & 428.964 & 3.14 & 0.018 & Residual \\
\hline Residual & 20 & 136.613 & & & \\
\hline Total & 29 & & & & \\
\hline
\end{tabular}


von der Meden et al. 2008, Pfaff et al. 2011) are shaped by supply-side factors, rather than early mortality. This predominance of supply-side influence is supported by findings of larval accumulation and retention within bays and upwelling shadows (Graham \& Largier 1997, Wing et al. 1998, Roughan et al. 2005, Mace \& Morgan 2006), as well as by the spatial consistency with which recruitment may occur across taxa (e.g. Pfaff et al. 2011). It seems then that the topography-associated pattern in the study region is set up largely during delivery and initial settlement and, being unchanged by post-settlement losses, propagates through to recruit and adult populations. Although our results support previous work identifying the importance of initial colonization patterns over post-colonization mortality in establishing mussel distributions (Hunt \& Scheibling 1998a), post-settlement mortality and density effects are known to be capable of de-coupling recruitment from initial settlement in other taxa (e.g. Shanks 2009) and are still likely to be important factors, particularly over smaller spatial scales.

Effects of predation on settler mortality can be significant for epibenthic invertebrates (Osman et al. 1992, Osman \& Whitlatch 1995); however, little is known about specific sources of mortality in mussel settlers under natural conditions. In terms of predation, whelks and a variety of benthic and pelagic species are known to prey on mussels as small as $2 \mathrm{~mm}$, but no substantial effects of predation on smaller settlers have been documented (Hunt \& Scheibling 1998b, Plass-Johnson et al. 2010). Rather, previous work on post-settlement mortality of Perna perna indicates that mortality increases with tidal height, suggesting abiotic sources of mortality related to increasing physiological stress (Bownes \& McQuaid 2009). In agreement, while dead mussels (empty valves) were present in samples from the present study, very few had been drilled by whelks (C. E. O. von der Meden pers. obs.). Given the likelihood of abiotic causes of mortality, but the lack of a topography-related pattern in mortality (which would have suggested an effect of wave force), heat stress and desiccation stress are the most probable causes of mortality in the present study. In terms of experimental technique, the most enduring problem with studies of post-settlement mortality is the separation of settler migration from actual mortality (Gosselin \& Qian 1997, Cole et al. 2000). None of the methods outlined in the introduction are able to make this separation, and the method used in the present study is no exception. Although it is argued (according to Assumption 3) that rates of migration to and from experimental substrata are equal, under field conditions the complex dynamics of settlement behaviour and spatio-temporal variability of settlement make this assumption tenuous. This has the frustrating implication that most studies of early mortality, including the present one, could either under- or overestimate mortality depending on relative rates of emigration/immigration. This issue is particularly relevant given the potentially strong effects of emigration on final population size in organisms like mussels (Bayne 1964).

The method of out-planting calcein-stained settlers, as done by Phillips (2002, 2004), is an improvement insofar as it allows immigrant settlers to be distinguished from original settlers. The loss of stained settlers however, can still not be categorically ascribed to either mortality or emigration, and the method may not be easily practicable on a large scale. Perhaps the most viable option for future research is an adaptation of the method of Walters (1992); here silicone vacuum grease was applied to experimental plates thereby permanently attaching settling larvae. In a post-settlement mortality context this method would allow the use of mapping or photographic techniques to follow settlement and mortality at short intervals without the confounding factor of emigration. The silicone grease does not affect settlement or attachment, and has been successfully used in a recent recruitment study by Dobretsov \& Wahl (2008). The application of practical methods for accurately establishing post-settlement mortality should allow future work to focus on better integrating information from all life stages.

Acknowledgements. This work is based upon research supported by the South African Research Chairs Initiative of the Department of Science and Technology and National Research Foundation. The authors are also indebted to F. McQuaid and Dr. V. Cole for mathematical advice and comments.

\section{LITERATURE CITED}

Bartol IK, Mann R, Luckenbach MW (1999) Growth and mortality of oysters (Crassostrea virginica) on constructed intertidal reefs: effects of tidal height and substrate level. J Exp Mar Biol Ecol 237:157-184

Bayne BL (1964) Primary and secondary settlement in Mytilus edulis L. (Mollusca). J Anim Ecol 33:513-523

Bishop MJ, Rivera JA, Irlandi EA, Ambrose WG, Peterson $\mathrm{CH}$ (2005) Spatio-temporal patterns in the mortality of bay scallop recruits in North Carolina: investigation of a life history anomaly. J Exp Mar Biol Ecol 315:127-146

Bownes S (2005) Habitat segregation in competing species of intertidal mussels in South Africa. PhD Thesis, Rhodes University, Grahamstown 
Bownes S, McQuaid CD (2009) Mechanisms of habitat segregation between an invasive and an indigenous mussel: settlement, post-settlement mortality and recruitment. Mar Biol 156:991-1006

> Bownes S, Barker NP, McQuaid CD (2008) Morphological identification of primary settlers and post-larvae of three mussel species from the coast of South Africa. Afr J Mar Sci 30:233-240

> Chan BKK, Williams GA (2003) The impact of physical stress and molluscan grazing on the settlement and recruitment of tetraclita species (Cirripedia: Balanomorpha) on a tropical shore. J Exp Mar Biol Ecol 284:1-23

> Cole RG, Hull PJ, Healy TR (2000) Assemblage structure, spatial patterns, recruitment, and post-settlement mortality of subtidal bivalve molluscs in a large harbour in north-eastern New Zealand. NZ J Mar Freshw Res 34: $317-329$

> Connell JH (1961) The influence of interspecific competition and other factors on the distribution of the barnacle Chthamalus stellatus. Ecology 42:710-723

Connell JH (1985) The consequences of variation in initial settlement vs. post-settlement mortality in rocky intertidal communities. J Exp Mar Biol Ecol 93:11-45

Davies G (1974) A method for monitoring spatfall of mussels (Mytilus edulis L.). J Cons int Explor Mer 36:27-34

$>$ Davis AR (1987) Variation in recruitment of the subtidal colonial ascidian Podoclavella cylindrica (Quoy and Gaimard): the role of substratum choice and early survival. J Exp Mar Biol Ecol 106:57-71

> Dobretsov S, Wahl M (2008) Larval recruitment of the blue mussel Mytilus edulis: the effect of flow and algae. J Exp Mar Biol Ecol 355:137-144

> Doherty PJ, Dufour V, Galzin R, Hixon MA, Meekan MG, Planes S (2004) High mortality during settlement is a population bottleneck for a tropical surgeonfish. Ecology 85:2422-2428

- Foster BA (1971) On the determinants of the upper limit of intertidal distribution of barnacles (Crustacea: Cirripedia). J Anim Ecol 40:33-48

Gaines SD, Bertness MD (1992) Dispersal of juveniles and variable recruitment in sessile marine species. Nature 360:579-580

$>$ Gosselin LA, Chia FS (1995) Characterizing temperate rocky shores from the perspective of an early juvenile snail: the main threats to survival of the newly hatched Nucella emarginata. Mar Biol 122:625-635

> Gosselin LA, Qian PY (1996) Early post-settlement mortality of an intertidal barnacle: a critical period for survival. Mar Ecol Prog Ser 135:69-75

> Gosselin LA, Qian PY (1997) Juvenile mortality in benthic marine invertebrates. Mar Ecol Prog Ser 146:265-282

Graham WM, Largier J (1997) Upwelling shadows as nearshore retention sites: the example of northern Monterey Bay. Cont Shelf Res 17:509-532

> Helson JG, Gardner JPA (2004) Contrasting patterns of mussel abundance at neighbouring sites: Does recruitment limitation explain the absence of mussels on Cook Strait (New Zealand) shores? J Exp Mar Biol Ecol 312:285-298

Hunt HL, Scheibling RE (1997) Role of early post-settlement mortality in recruitment of benthic marine invertebrates. Mar Ecol Prog Ser 155:269-301

Hunt HL, Scheibling RE (1998a) Spatial and temporal variability of patterns of colonization by mussels (Mytilus trossulus, $M$. edulis) on a wave-exposed rocky shore. Mar Ecol Prog Ser 167:155-169
Hunt HL, Scheibling RE (1998b) Effects of whelk (Nucella lapillus (L.)) predation on mussel (Mytilus trossulus (Gould), M. edulis (L.)) assemblages in tidepools and on emergent rock on a wave-exposed rocky shore in Nova Scotia, Canada. J Exp Mar Biol Ecol 226:87-113

Hurlbut CJ (1991) Community recruitment: settlement and juvenile survival of seven co-occuring species of sessile marine invertebrates. Mar Biol 109:507-515

Iwasaki K (1995) Factors delimiting the boundary between vertically contiguous mussel beds of Spetifer virgatus (Wiegmann) and Hormomya mutabilis (Gould). Ecol Res 10:307-320

Jarrett JN (2000) Temporal variation in early mortality of an intertidal barnacle. Mar Ecol Prog Ser 204:305-308

> Lagos NA, Navarrete SA, Véliz F, Masuero A, Castilla JC (2005) Meso-scale spatial variation in settlement and recruitment of intertidal barnacles along the coast of central Chile. Mar Ecol Prog Ser 290:165-178

Luckenbach MW (1984) Settlement and early post-settlement survival in the recruitment of Mulinia lateralis (Bivalvia). Mar Ecol Prog Ser 17:245-250

> Mace AJ, Morgan SG (2006) Larval accumulation in the lee of a small headland: implications for the design of marine reserves. Mar Ecol Prog Ser 318:19-29

> Marshall DJ, Keough MJ (2003) Effects of settler size and density on early post-settlement survival of Ciona intestinalis in the field. Mar Ecol Prog Ser 259:139-144

> McQuaid CD, Phillips TE (2006) Mesoscale variation in reproduction, recruitment and population structure of intertidal mussels with low larval input: a bay/open coast comparison. Mar Ecol Prog Ser 327:193-206

> Minchinton TE, Scheibling RE (1993) Free space availability and larval substratum selection as determinants of barnacle population structure in a developing rocky intertidal community. Mar Ecol Prog Ser 95:233-244

> Moksnes PO, Pihl L, van Montfrans J (1998) Predation on postlarvae and juveniles of the shore crab Carcinus maenas: importance of shelter, size and cannibalism. Mar Ecol Prog Ser 166:211-225

Moreno CA (1995) Macroalgae as a refuge from predation for recruits of the mussel Choromytilus chorus (Molina, 1782) in Southern Chile. J Exp Mar Biol Ecol 191: 181-193

Naylor JR, McShane PE (2001) Mortality of post-settlement abalone Haliotis iris caused by conspecific adults and wave exposure. NZ J Mar Freshw Res 35:363-369

Nicastro KR, Zardi GI, McQuaid CD (2008) Movement behaviour and mortality in invasive and indigenous mussels: resilience and resistance strategies at different spatial scales. Mar Ecol Prog Ser 372:119-126

> Osman RW, Whitlatch RB (1995) Predation on early ontogenetic life stages and its effect on recruitment into a marine epifaunal community. Mar Ecol Prog Ser 117: $111-126$

> Osman RW, Whitlatch RB, Malatesta RJ (1992) Potential role of micro-predators in determining recruitment into a marine community. Mar Ecol Prog Ser 83:35-43

> Peteiro LG, Filgueira R, Labarta U, Fernandez-Reiriz J (2007) Settlement and recruitment patterns of Mytilus galloprovincialis L. in the Ria de Aares-Betanzos (NW Spain) in the years 2004/2005. Aquacult Res 38:957-964

Pfaff MC, Branch GM, Wieters EA, Branch RA, Broitman BR (2011) Upwelling intensity and wave exposure determine recruitment of intertidal mussels and barnacles in the southern Benguela upwelling region. Mar Ecol Prog 
Ser 425:141-152

Phillips NE (2002) Effects of nutrition-mediated larval condition on juvenile performance in a marine mussel. Ecology 83:2562-2574

Phillips NE (2004) Variable timing of larval food has consequences for early juvenile performance in a marine mussel. Ecology 85:2341-2346

Plass-Johnson JG, McQuaid CD, Porri F (2010) Top-down effects on intertidal mussel populations: assessing two predator guilds in a South African marine protected area. Mar Ecol Prog Ser 411:149-159

Ray MR, Stoner AW (1995) Growth, survivorship, and habitat choice in a newly settled seagrass gastropod, Strombus gigas. Mar Ecol Prog Ser 123:83-94

Roegner GC, Mann R (1995) Early recruitment and growth of the American oyster Crassostrea virginica (Bivalvia: Ostreidae) with respect to tidal zonation and season. Mar Ecol Prog Ser 117:91-101

Roughan M, Mace AJ, Largier JL, Morgan SG, Fisher JL, Carter ML (2005) Subsurface recirculation and larval retention in the lee of a small headland: a variation on the upwelling shadow theme. J Geophys Res 110:C4 doi: 10.1029/2005JC002898

Searcy SP, Sponaugle S (2001) Selective mortality during the larval-juvenile transition in two coral reef fish. Ecology 82:2452-2470

Seed R (1969) The ecology of Mytilus edulis L. (Lamellibranchiata) on exposed rocky shores. II. Growth and mortality. Oecologia 3:317-350

Shanks AL (2009) Barnacle settlement versus recruitment as indicators of larval delivery. I. Effects of post-settlement mortality and recruit density. Mar Ecol Prog Ser 385: 205-216

Shields JL, Barnes P, Heath DD (2008) Growth and survival differences among native, introduced and hybrid blue mussels (Mytilus spp.): genotype, environment and interaction effects. Mar Biol 154:919-928

Stoner DS (1990) Recruitment of a tropical colonial ascidian:

Editorial responsibility: Richard Osman,

Edgewater, Maryland, USA relative importance of pre-settlement vs. post-settlement processes. Ecology 71:1682-1690

Tan WH (1975) The effects of exposure and crawling behaviour on the survival of recently settled green mussel (Mytilus viridis L.). Aquaculture 6:357-368

Thorson G (1966) Some factors influencing the recruitment and establishment of marine benthic communities. Neth J Sea Res 3:267-293

von der Meden CEO, Porri F, Erlandsson J, McQuaid CD (2008) Coastline topography affects the distribution of indigenous and invasive mussels. Mar Ecol Prog Ser 372: 135-145

von der Meden CEO, Porri F, McQuaid CD, Faulkner K, Robey J (2010) Fine-scale ontogenetic shifts in settlement behaviour of mussels: changing responses to biofilm and conspecific settler presence in Mytilus galloprovincialis and Perna perna. Mar Ecol Prog Ser 411: 161-171

Walters LJ (1992) Field settlement locations on subtidal marine hard substrata: Is active larval exploration involved? Limnol Oceanogr 37:1101-1107

> Walters LJ, Wethey DS (1996) Settlement and early post-settlement survival of sessile marine invertebrates on topographically complex surfaces: the importance of refuge dimensions and adult morphology. Mar Ecol Prog Ser 137:161-171

Wethey DS (1985) Local and regional variation in settlement and survival in the littoral barnacle Semibalanus balanoides (L.): patterns and consequences. In: Moore PG, Seed R (eds) Ecology of rocky coasts. Hodder and Stoughton, London, p 194-202

> Wing SR, Botsford LW, Ralston SV, Largier J (1998) Meroplanktonic distribution and circulation in a coastal retention zone of the northern California upwelling system. Limnol Oceanogr 43:1710-1721

Zobell CE, Allen EC (1935) The significance of marine bacteria in the fouling of submerged surfaces. J Bacteriol 29: 239-251

Submitted: January 30, 2012; Accepted: May 31, 2012 Proofs received from author(s): August 14, 2012 